\title{
KUPASAN SYAIR KARANGAN PURNOMO
}

\section{Legi Aleksa}

Universitas Nahdlatul Ulama Sidoarjo

\section{PENDAHULUAN}

Puisi adalah jenis seni yang memungkinkan penulis untuk menggunakan imajinasi dan kreativitas mereka yang tidak diizinkan oleh bentuk sastra lain. Anda diberi berbagai teknik dan gaya yang jauh lebih luas, dan elemen-elemen untuk dikerjakan. Namun, Anda harus menggunakannya dengan hati-hati, unik, dan bijak. Ini adalah perbuatan yang sulit untuk dilakukan, tetapi juga merupakan favorit di antara banyak seniman. Banyak penulis menganggap puisi sebagai bentuk sastra paling sulit namun paling memuaskan. Dan memang demikian. Jumlah elemen, teknik, dan kreativitas tidak terjawab di dunia prosa (Hess, 2019).

Puisi merupakan koleksi literasi melibatkan emosi dan ide (A Research Guide, 2019). Puisi dapat berupa hal-hal yang bergaris, seringkali dengan rima, yang bertentangan 
dengan kalimat dan paragraf; puisi juga bisa menjadi hal yang baik, tidak seperti orang yang lamban atau hanya memberi informasi. Tetapi jika prosa yang baik bisa menjadi puitis, sebuah novel bisa menjadi "puisi murni," dan puisi bisa jadi biasa saja, maka tidak jelas apa yang dibicarakan orang, sungguh. Atau lebih tepatnya, itu jelas kecuali para teoretikus yang mencoba menghasilkan definisi. Puisi adalah hal yang menggetarkan, sementara puisi adalah hal yang buruk dengan sebelas pembaca, delapan di antaranya anggota keluarga besar penyair (Searls, 2015).

\section{PENYAIR}

Penyair bernama lengkap Agung Purnomo dan tumbuh di Sidoarjo. Beliau merupakan salah satu seorang dosen di Indonesia. Berikut tulisan syair beliau telah disebarkan secara luas melalui penerbit nasional, yaitu: STIEBA Madura Press, ITB Press, dan UNUSIDA Press. 


\section{Tabel 1. Syair Karangan Agung Purnomo}

\begin{tabular}{|c|c|c|c|c|c|c|}
\hline No & $\begin{array}{l}\text { Judul } \\
\text { Puisi }\end{array}$ & Penulis & $\begin{array}{l}\text { Jenis } \\
\text { puisi }\end{array}$ & $\begin{array}{l}\text { Judul } \\
\text { buku }\end{array}$ & Penerbit & Tahun \\
\hline 1 & Berpulang & $\begin{array}{c}\text { Agung } \\
\text { Purnomo }\end{array}$ & $\begin{array}{l}\text { Puisi } \\
\text { epitaf }\end{array}$ & $\begin{array}{l}\text { Syair } \\
\text { Nimala }\end{array}$ & $\begin{array}{l}\text { STIEBA } \\
\text { Madura } \\
\text { Press }\end{array}$ & 2019 \\
\hline 2 & $\begin{array}{c}\text { Bapak } \\
\text { Samsuri }\end{array}$ & $\begin{array}{c}\text { Agung } \\
\text { Purnomo, } \\
\text { Nur } \\
\text { Asitah }\end{array}$ & $\begin{array}{c}\text { Puisi } \\
\text { Clerihew }\end{array}$ & $\begin{array}{l}\text { Dhalubang } \\
\text { Marta }\end{array}$ & $\begin{array}{l}\text { STIEBA } \\
\text { Madura } \\
\text { Press }\end{array}$ & 2019 \\
\hline 3 & Dua Kaki & $\begin{array}{c}\text { Agung } \\
\text { Purnomo }\end{array}$ & $\begin{array}{l}\text { Puisi } \\
\text { Bebas }\end{array}$ & $\begin{array}{l}\text { Kidung } \\
\text { Nawala } \\
\text { (Jilid 2) }\end{array}$ & $\begin{array}{l}\text { UNUSIDA } \\
\text { Press }\end{array}$ & 2018 \\
\hline 4 & Tangisnya & $\begin{array}{c}\text { Agung } \\
\text { Purnomo, } \\
\text { Nur } \\
\text { Asitah }\end{array}$ & $\begin{array}{l}\text { Puisi } \\
\text { Naratif }\end{array}$ & $\begin{array}{l}\text { Bhumi } \\
\text { Bawera }\end{array}$ & $\begin{array}{l}\text { STIEBA } \\
\text { Madura } \\
\text { Press }\end{array}$ & 2019 \\
\hline 5 & Pandai & $\begin{array}{c}\text { Agung } \\
\text { Purnomo, } \\
\text { Nur } \\
\text { Asitah }\end{array}$ & $\begin{array}{l}\text { Puisi } \\
\text { Riddle }\end{array}$ & $\begin{array}{l}\text { Tolesan } \\
\text { Aditi }\end{array}$ & $\begin{array}{l}\text { STIEBA } \\
\text { Madura } \\
\text { Press }\end{array}$ & 2019 \\
\hline 6 & $\begin{array}{l}\text { Sepekan } \\
\text { Awal } \\
\text { Tanpamu }\end{array}$ & $\begin{array}{l}\text { Agung } \\
\text { Purnomo, } \\
\text { Nur } \\
\text { Asitah }\end{array}$ & $\begin{array}{l}\text { Puisi } \\
\text { bersekuen }\end{array}$ & $\begin{array}{l}\text { Arebhan } \\
\text { Helai }\end{array}$ & $\begin{array}{l}\text { STIEBA } \\
\text { Madura } \\
\text { Press }\end{array}$ & 2019 \\
\hline 7 & Cantik & $\begin{array}{l}\text { Agung } \\
\text { Purnomo, } \\
\text { Nur } \\
\text { Asitah }\end{array}$ & $\begin{array}{l}\text { Puisi } \\
\text { Jenaka } \\
\text { Limerick }\end{array}$ & $\begin{array}{l}\text { Lembhar } \\
\text { Jiwana }\end{array}$ & $\begin{array}{l}\text { STIEBA } \\
\text { Madura } \\
\text { Press }\end{array}$ & 2019 \\
\hline 8 & $\# \mathrm{CH} 1$ & $\begin{array}{l}\text { Agung } \\
\text { Purnomo }\end{array}$ & $\begin{array}{l}\text { Puisi } \\
\text { Bebas }\end{array}$ & $\begin{array}{l}\text { Kidung } \\
\text { Nawala } \\
\text { (Jilid 1) }\end{array}$ & $\begin{array}{l}\text { UNUSIDA } \\
\text { Press }\end{array}$ & 2018 \\
\hline 9 & Menyala & $\begin{array}{l}\text { Agung } \\
\text { Purnomo }\end{array}$ & $\begin{array}{l}\text { Puisi } \\
\text { Haiku }\end{array}$ & $\begin{array}{l}\text { Tenta } \\
\text { Kimaya }\end{array}$ & $\begin{array}{l}\text { STIEBA } \\
\text { Madura } \\
\text { Press }\end{array}$ & 2019 \\
\hline 10 & Kita & $\begin{array}{l}\text { Agung } \\
\text { Purnomo, } \\
\text { Elsa } \\
\text { Rosyidah }\end{array}$ & $\begin{array}{l}\text { Puisi } \\
\text { Bebas }\end{array}$ & $\begin{array}{l}\text { Suweda } \\
\text { Ate }\end{array}$ & $\begin{array}{l}\text { STIEBA } \\
\text { Madura } \\
\text { Press }\end{array}$ & 2019 \\
\hline 11 & $\begin{array}{l}\text { Rindu di } \\
\text { Ubun- } \\
\text { Ubun }\end{array}$ & $\begin{array}{l}\text { Agung } \\
\text { Purnomo }\end{array}$ & $\begin{array}{l}\text { Puisi } \\
\text { Bebas }\end{array}$ & $\begin{array}{l}\text { Rassana } \\
\text { Jlantir }\end{array}$ & $\begin{array}{l}\text { STIEBA } \\
\text { Madura } \\
\text { Press }\end{array}$ & 2019 \\
\hline
\end{tabular}




\section{KUPASAN}

Inilah tajuk-tajuk syair gubahan Agung Purnomo yakni: rindu di ubun-ubun (Purnomo, 2019c), sepekan awal tanpamu (Purnomo \& Asitah, 2019d), \#CH1 (Purnomo, 2018a), cantik (Purnomo \& Asitah, 2019b), berpulang (Purnomo, 2019a), dua kaki (Purnomo, 2018b), bapak Samsuri (Purnomo \& Asitah, 2019a), menyala (Purnomo, 2019b), tangisnya (Purnomo \& Asitah, 2019e), pandai (Purnomo \& Asitah, 2019c), dan kita (Purnomo \& Rosyidah, 2019).

Agung Purnomo menulis sebelas puisi dengan gaya epitaf, clerihew, bebas, riddle, bersekuen, jenaka limerik dan haiku. Puisi diterbikan pada tahun 2018 dan tahun 2019. Puisi enak dibaca dan mudah dipahami oleh pembaca. 


\section{REFERENCES}

A Research Guide. (2019). Poetry Structure and Its Usage in Poems. Retrieved June 23, 2019, from

https://www.aresearchguide.com/poetrystructure.html

Hess, G. R. (2019). Poetry Definition - A True Description and Explanation. Retrieved June 26, 2019, from https://www.poemofquotes.com/articles/poet ry_definition.php

Purnomo, A. (2018a). \#CH1. In Kidung Nawala (Jilid 1). Sidoarjo: UNUSIDA Press.

Purnomo, A. (2018b). Dua Kaki. In Kidung Nawala (Jilid 2). Sidoarjo: UNUSIDA Press.

Purnomo, A. (2019a). Berpulang. In Syair Nimala. Sumenep: STIEBA Madura Press. Purnomo, A. (2019b). Menyala. In Tenta Kimaya. Sumenep: STIEBA Madura Press.

Purnomo, A. (2019c). Rindu di Ubun-Ubun. In Rassana Jlantir. Sumenep: STIEBA Madura Press.

Purnomo, A., \& Asitah, N. (2019a). Bapak Samsuri. In Dhalubang Marta. Sumenep: STIEBA Madura Press.

Purnomo, A., \& Asitah, N. (2019b). Cantik. In Lembhar Jiwana. Sumenep: STIEBA Madura Press.

Purnomo, A., \& Asitah, N. (2019c). Pandai. In Tolesan Aditi. Sumenep: STIEBA Madura Press. 
Purnomo, A., \& Asitah, N. (2019d). Sepekan Awal Tanpamu. In Arebhan Helai.

Sumenep: STIEBA Madura Press.

Purnomo, A., \& Asitah, N. (2019e). Tangisnya. In Bhumi Bawera. Sumenep: STIEBA Madura Press.

Purnomo, A., \& Rosyidah, E. (2019). Kita. In Suweda Ate. Sumenep: STIEBA Madura Press.

Searls, D. (2015). Write Tight. Retrieved June 25, 2019, from https://www.theparisreview.org/blog/2015/04 /21/write-tight/ 